\title{
"SDGs and the ability to manage change within the European green deal: The case of Ukraine"
}

\begin{tabular}{|c|c|}
\hline AUTHORS & $\begin{array}{l}\text { Hanna Shevchenko (D https://orcid.org/0000-0002-0817-7754 } \\
\mathbb{R} \text { https://publons.com/researcher/AAG-8703-2019 } \\
\text { Mykola Petrushenko (D https://orcid.org/0000-0003-0098-7872 } \\
\mathbb{R} \text { https://publons.com/researcher/AAG-8711-2019 } \\
\text { Borys Burkynskyi (D https://orcid.org/0000-0001-9303-0898 } \\
\mathbb{R} \text { https://publons.com/researcher/U-9714-2017 } \\
\text { Nina Khumarova (D https://orcid.org/0000-0001-5255-8004 } \\
\mathbb{R} \text { https://publons.com/researcher/2004596/nina-i-khumarova/ }\end{array}$ \\
\hline ARTICLE INFO & $\begin{array}{l}\text { Hanna Shevchenko, Mykola Petrushenko, Borys Burkynskyi and Nina } \\
\text { Khumarova (2021). SDGs and the ability to manage change within the European } \\
\text { green deal: The case of Ukraine. Problems and Perspectives in Management, } \\
\text { 19(1), 53-67. doi:10.21511/ppm.19(1).2021.05 }\end{array}$ \\
\hline DOI & http://dx.doi.org/10.21511/ppm.19(1).2021.05 \\
\hline RELEASED ON & Tuesday, 26 January 2021 \\
\hline RECEIVED ON & Tuesday, 24 November 2020 \\
\hline ACCEPTED ON & Wednesday, 20 January 2021 \\
\hline LICENSE & $\begin{array}{l}(\mathrm{c}) \mathrm{EY} \\
\text { This work is licensed under a Creative Commons Attribution } 4.0 \text { International } \\
\text { License }\end{array}$ \\
\hline JOURNAL & "Problems and Perspectives in Management" \\
\hline ISSN PRINT & $1727-7051$ \\
\hline ISSN ONLINE & $1810-5467$ \\
\hline PUBLISHER & LLC "Consulting Publishing Company "Business Perspectives" \\
\hline FOUNDER & LLC "Consulting Publishing Company "Business Perspectives" \\
\hline $0^{\circ}$ & $\begin{array}{l}\text { ニニ } \\
\text { 三: }\end{array}$ \\
\hline NUMBER OF REFERENCES & NUMBER OF FIGURES \\
\hline 47 & 1 \\
\hline
\end{tabular}

(C) The author(s) 2021. This publication is an open access article. 


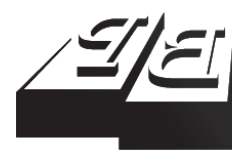

BUSINESS PERSPECTIVES

(2)

LLC "CPC "Business Perspectives" Hryhorii Skovoroda lane, 10, Sumy, 40022, Ukraine www.businessperspectives.org

Received on: $24^{\text {th }}$ of November, 2020 Accepted on: $20^{\text {th }}$ of January, 2021 Published on: $26^{\text {th }}$ of January, 2021

(๑) Hanna Shevchenko, Mykola Petrushenko, Borys Burkynskyi, Nina Khumarova, 2021

Hanna Shevchenko, Doctor of Economics, Institute of Market Problems and Economic-Ecological Research, National Academy of Sciences of Ukraine, Ukraine.

Mykola Petrushenko, Doctor of Economics, Institute of Market Problems and Economic-Ecologica Research, National Academy of Sciences of Ukraine, Ukraine. (Corresponding author)

Borys Burkynskyi, Doctor of Economics, Professor, Academician of the National Academy of Sciences of Ukraine, Institute of Market Problems and Economic-Ecological Research, National Academy of Sciences of Ukraine, Ukraine.

Nina Khumarova, Doctor of Economics, Professor, Institute of Market Problems and EconomicEcological Research, National Academy of Sciences of Ukraine, Ukraine.

This is an Open Access article, distributed under the terms of the Creative Commons Attribution 4.0 International license, which permits unrestricted re-use, distribution, and reproduction in any medium, provided the original work is properly cited.

Conflict of interest statement: Author(s) reported no conflict of interest
Hanna Shevchenko (Ukraine), Mykola Petrushenko (Ukraine),

Borys Burkynskyi (Ukraine), Nina Khumarova (Ukraine)

\section{SDGS AND THE ABILITY}

TO MANAGE CHANGE WITHIN

THE EUROPEAN GREEN DEAL: THE CASE OF UKRAINE

\begin{abstract}
The European Green Deal by the European Commission is an ambitious policy aimed at achieving a climate-neutral economy. For Ukraine, the EGD is a priority in accelerating its European integration processes until 2030. The study aims to determine the country's ability to manage change towards the implementing the concept of sustainable development, adjusted in accordance with the European Green Deal's provisions, based on the analysis of SDG achievements in Ukraine, as well as on the identified quantitative results of readiness for change. The ability to manage change is determined by applying methods of analysis and generalization of descriptive statistics related to aspects of sustainable development and the EGD, as well as quantifying intermediate and final integral values of change management in Ukraine in the EGD context. The relationship between the SDGs and the EGD provisions on the "need for very high sustainability - sufficiency of weak sustainability" continuum was prioritized. The proposed provisions of the cooperation program provide for a thorough analysis of Ukrainian, European and global trends in the field of climate change and relevant sustainable development policies, use of statistical data, constant monitoring of indicators characterizing the dynamics of socio-economic, environmental and demographic status of the state and regions in connection with climate change, generalization of the experience of a climate-neutral economy, green energy, European integration processes, etc. The program is interdisciplinary in nature, which allows to get a comprehensive vision and provide a systematic solution to the problem of transforming the national economy in accordance with the European Green Deal.
\end{abstract}

\section{Keywords} sustainability, European Green Deal, change readiness, development program, Ukraine

\section{JEL Classification $\quad$ Q01, Q56, R11, R58}

\section{INTRODUCTION}

The situation related to global warming caused by anthropogenic activities continues to deteriorate. In 2019, the highest level of carbon dioxide in the atmosphere was recorded and, accordingly, 2010-2019 is the warmest decade for the entire observation period. In 2020, due to the restrictions on the functioning and development of transport and other sectors of the world economy due to the coronavirus pandemic, the projected reduction in greenhouse gas emissions is about 6 percent, but this improvement is temporary (United Nations, 2020). Therefore, the fight against climate change is still relevant and is one of the most discussed political and transdisciplinary scientific problems, regardless of other global challenges, and, accordingly, is one of the defining evolutionary factors of the sustainable development concept.

The European Union is trying to become a global leader in climate change by 2050 (European Commission, 2020). The European Green Deal (EGD) by the European Commission is a policy with the ambitious goal of achieving a climate-neutral economy. This course builds 
on the 2030 Global Goals (United Nations, 2020a) and aims to accelerate their achievement by EU countries relative to the rest of the world. Thus, the European Union declares an increase in its status in competition with other centers of world politics and economic development. This competition will have a positive effect in the form of additional motivation in the field of climate change and environmental economy at the global level (EuroMemo Group, 2019). The EGD must also ensure the reality of long-term implementation of SDGs, despite the need to address pressing crisis challenges such as the coronavirus pandemic, terrorist threats and migration related to hostilities, dictatorships, environmental disasters, etc.

The EGD's policy is open and, from the very beginning (officially, from December 2019), is aimed at partnerships, primarily with neighboring countries to the European Union. In 2030-2050, European countries such as Ukraine intend and have a chance to join the EU. Accelerating the process of European integration depends on the country's active participation in programs and strategies initiated by the EU. In this sense, the EGD is a priority. First of all, Ukraine needs scientific and applied research on the factors for the development of renewable energy, improving the quality of the environment, efficient use of natural resources and other areas of a climate-neutral economy and related social processes. Without these studies, which must be based on real facts and figures on the socio-economic and environmental situation in Ukraine, it is impossible to involve it in the effective implementation of the EGD, and thus justify investment in sustainable development and accelerate European integration.

Before defining Ukraine's role in joint actions aimed at accelerating sustainable development on the European continent (Government of Ukraine, 2020) as well as around the world (OECD, 2020), it is necessary to assess the level of its previous success in achieving national SDGs (Sustainable Development Goals: Ukraine, 2020). In other words, the previous governance and economic efforts reflected in the country's progress towards sustainability are a determining factor in its readiness for further comprehensive change.

\section{LITERATURE REVIEW}

The new set of the EU political green initiatives is original, first of all, by its ambition. Otherwise, it is similar to its predecessors, as well as to modern views on economic and environmental activities embodied in national and regional green development programs. Thus, in the United States, the Green New Deal is "... a congressional resolution that lays out a grand plan for tackling climate change" (Friedman, 2019) and includes the following components: switching from fossil fuels to non-traditional energy sources, limiting greenhouse gas emissions in the context of combating global warming, large-scale job creation in the field of clean energy. This resolution is a democratic initiative that increases its conceptual importance, but significantly reduces its effectiveness in today's economic realities. Comparing the US and EU resolutions, the topic of leadership in achieving zero carbon emissions by 2050 stands out. The US government proposals for a green resolution in an industry context are as follows: construction - environmental and energy modernization of each building, tourism - replacing air travel with highspeed rail, food - gradually replacing livestock by crop production, if mentally and technologically possible. The investment required to implement the resolution is open and usually depends on the financial return for each trillion dollars invested.

In line with the new understanding of the Green New Deal, the responsibility of the policy expands significantly (Ikerd, 2019) and is not limited to environmental aspects, but returns to the category of sustainability and inclusiveness. In particular, this applies to food and food safety as an important element in protecting consumers' rights and ensuring their satisfactory health. A similar view of the content of the Green New Deal is outlined in Seitz and Krutka (2020).

The new green policy is equally relevant for China, whose rapid economic growth over three decades has caused enormous environmental damage (Li, 2014). Modern China is aware of the inevitability 
of changes in the field of environmental protection and environmental management, which are directly related not only to the obvious negative consequences for public health, but also for further economic development, especially in the long run.

The Green Deal was a 2013-2016 British policy that failed (detailed criticism in Rosenow \& Eyre, 2016): The proposed innovative energy efficiency measures fell short of the cost. The main reason for the failure was a lack of motivation for homeowners as the main target group. They did not believe that the loans provided at high enough interest rates were beneficial due to the resulting energy savings (the so-called Golden rule). The British Green Deal resulted in only about 2,000 renovated homes in three years of the policy. This could have been avoided by providing a more favorable financial environment, a well-thought-out marketing campaign, and engaging other target groups, including large investors, the active public, and the authorities responsible for energy and wealth development.

The structure of the Green Deal target group (Pettifor et al., 2015) included both effective and ineffective renovators as well as non-renovators. All these subgroups may have been interested in the presented policy, but it turned out that this was not the case. Accordingly, the assessment of the potential volume of renovations and the necessary investment did not take into account all the nuances of motivating homeowners.

As expected, the publicity brought by the EGD resolution, "a third alternative to green growth", could not fail to generate much criticism, both politically and scientifically (Ossewaarde \& Ossewaarde-Lowtoo, 2020). Thus, in general, there are doubts about the political and economic capacity of the "the first comprehensive plan to achieve climate neutrality at a continental scale", despite the fact that the announced funding for the plan is 1 trillion euros (Storm, 2020). According to Lucchese and Pianta (2020), increasing the ambition of the climate change policy goal is insufficiently justified, in particular given the continuity of financial investment and a lack of a clear strategy to achieve this goal, especially in the context of significant differences between in- dustrialization and environmental policy in the European Union. Another important argument is that it has not been long since the 2008 financial crisis to lay a solid foundation for a neutral climate policy, which in a sense is a stress for any country's economy. Although the very idea of taking immediate measures to suspend anthropogenic climate change is undeniable. Among other weaknesses of the European Green Deal, the authors also mention a lack of political influence and a lack of a realistic framework for green business activities, in particular through pricing and taxation tools, including regional differences in climate policies. In addition, there is no deliberate coherence with other types of policies in the overall transformation framework, in particular by drawing parallels with the 2030 Sustainable Development Goals. As a result, a return to the so-called "political project" is mentioned again.

Pianta and Lucchese (2020) also argue that EGD's disadvantages include the lack of resources to achieve the stated overly ambitious goals. Instead, a "a broader range of 'green' industrial policies" is needed. The EU new green policy proposes targets for 2030 (for example, halving emissions compared to 1990) and 2050 (Schiermeier, 2020).

However, this approach is more of a political gimmick than an economically sound forecast, especially given the global challenges since the 2008 financial crisis. In the short term, climate campaigners say the EGD is not producing concrete meaningful results.

EDG is a policy that provides for the development of a comprehensive EU development strategy based on the concept of sustainable development, but a detailed rationale for how environmental factors will balance with social and economic factors (Matvieieva et al., 2019) is missing from the policy documents. Meanwhile, the EDG itself is only one of the priorities of the EU in the medium term (European Commission, 2020), along with "a Europe fit for the digital age", "an economy that works for people" and others.

Pastukhova et al. (2020) believe that the EU cannot limit its actions in the field of renewable and secure energy only to the EGD, given the geopolitical and geo-economic challenges. We need not 
only a more stringent energy policy based on market principles and government support, but also the modernization of EU energy diplomacy, in particular, towards expanding cooperation with neighboring countries and regions, which are existing and potential energy suppliers.

Fuchs et al. (2020) also blamed the EDG initiative for negatively affecting global sustainability, causing environmental damage to agriculture and related industries in other countries. By tightening environmental standards in the domestic market for agricultural products, the EU remains blind to the compliance of imports with these standards (in 2019, the European Union bought one-fifth of the crop and one-tenth of meat abroad). As a result, deforestation continues in developing countries and countries with much less stringent environmental policies such as Brazil or Indonesia, pesticides are used, GMOs are not restricted, etc. In addition, new international political agreements, as a rule, do not oblige to raise environmental standards, but only declare the possibility of voluntarily initiating the improvement of environmentally oriented activities.

Instead, publications expressing views on support for the EGD reveal the following issues: combining innovative and investment components of a new climate policy (de Oliveira et al., 2020), providing not only environmental but also safe energy, taking into account the need to overcome the economic crisis (Hainsch et al., 2020), solving the problem of zero soil pollution as the basis for the development of agriculture and farming (Montanarella \& Panagos, 2021), etc. In addition, the European Commission, in response to criticism of the EGD funding, proposes to use mutual funds accumulated in areas corresponding to the new green course, as well as the principle of "fair transition", which considers the development and local problems of each EU country (Suttor-Sorel et al., 2019).

EGD also aims to implement policies in various sectors of the economy aimed at creating an eco-friendly environment for humans. Also, in response to the need to change the urban environment, the green course will increase the area of green spaces, bringing them closer to where people live and work (Haines \& Scheelbeek, 2020).
The feasibility of introducing ambitious comprehensive programs with a strong political context, such as the EGD, is explained by the fact that only economic instruments, in particular pricing instruments, cannot stimulate innovation aimed at decarbonization in industry (Evans et al., 2020). According to Siddi (2020), the EGD is a very real political project, which, however, in a crisis of socio-economic conditions requires much more funding, as well as improved development of institutions that ensure the successful implementation of the new policy to achieve climate neutrality. Sikora (2020) also stresses the need to implement this policy at the constitutional level, in particular, on the principles of sustainability and solidarity.

Given the above, this study aims to determine the country's ability to manage change towards the implementation of the concept of sustainable development, adjusted in accordance with the EGD provisions. This was done by analyzing the level of SDG achievements in Ukraine, as well as on the basis of certain quantitative results of readiness for change, determining the priority provisions of the target program for the development of Ukrainian-European cooperation with the pilot name "European integration green transformation of the Ukrainian economy for a sustainable future in 2030 and 2050".

\section{DATA AND METHODOLOGY}

This study determines the ability to manage change, first of all, by its justification at the conceptual level, in the analysis and generalization of descriptive statistics relevant for the sustainable development aspects and the EGD's position, namely to form the structure of the integrated indicator of the ability to change (similar to the concept of determining the Change Readiness Index (KPMG International Cooperative, 2019)). Second, the intermediate and final integrated values of Ukraine's potential for change management in the context of the EGD are quantified. The estimation algorithm consists of the following stages:

- Definition of indicators in accordance with 17 Sustainable Development Goals for 2015, 2019 and 2030 (benchmarks) to form a statistical basis for quantifying Ukraine's progress 
in achieving the SDGs (columns 1-5 in Table A1; the secondary data used are shown in the national survey (Sustainable Development Goals: Ukraine, 2020)). To compare them with the achievements of sustainable development in the EU, data from Eurostat (2020) were used, taking into account global trends, according to the UN report (2019b): the 2030 benchmarks for Ukraine are close to the corresponding EU's sustainable development indicators for 2015.

- Analysis of progress/regression, according to the direction of variability (increase/decrease) of the indicator, determining the desirability/undesirability of variability (column 6 of Table A1) in the implementation of medium-term planning (column 7 of Table A1) and long-term planning (column 8 of Table A1), and accelerating changes to sustainability in line with the ambition of the EGD (expressed through the product of values consistent with medium and long-term planning) (column 9 of Table A1).

- Determining the integrated change readiness indicator using the method of weighted geometric mean (taking into account the recommendations by Shevchenko et al. 2020), namely:

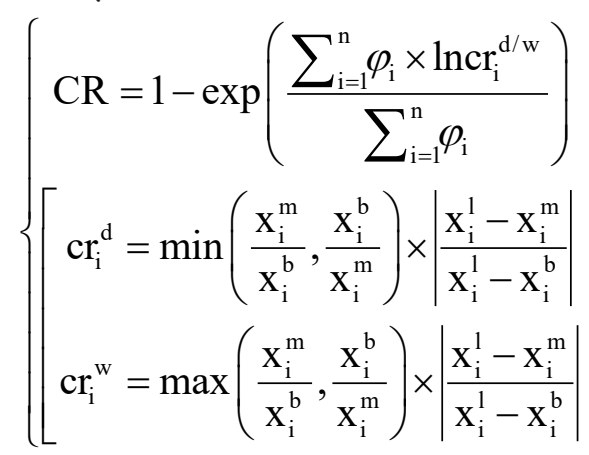

where $C R$ is the integrated change readiness indicator $(C R \rightarrow 1)$ defined within one of the SDGs 2030 (column 13 of Table A1); $c r_{i}^{d / w}, c r_{i}^{d}$, and $c r_{i}^{w}$ are single $i$-th $(i=1, \ldots, n)$ change readiness indicators (determined according to the $i$-th indicator within one of the SDGs), whose value may vary in the desired $(d)$ or wrong $(w)$ direction, respectively; $x_{i}^{b}$, $x_{i}^{m}$, and $x_{i}^{l}$ are the values of the $i$-th indicator within one of the SDGs in the base (b), medium-term $(m)$ and long-term $(l)$ periods, respectively; and $\varphi_{i}$ is the weight of the $i$-th unit change readiness indicator (column 11 of Table A1) (within one of the SDGs, $\left.\sum \varphi_{i}=1\right)$.

\section{RESULTS}

Before moving on to the results that determine the level of Ukraine's readiness to manage change within the framework of the Sustainable Development Goals in accordance with the European Green Deal guidelines, it is necessary to consider the specifics of management within the EGD, namely:

- a new approach to management as a combination of regulation and motivation based on sustainability;

- barriers to implementation at the national level; and

- harmonization of environmental standards at the level of the transition economy.

When implementing the European Green Deal, attention should be paid to the contradiction associated with the simultaneous operation of the EU's 2030 Climate and Energy Policy Framework, which is in line with the Paris Agreement (Sustainable Development Mechanism instead of Clean Development Mechanism). In general, the European Green Deal is a search for a new combination of regulatory and motivational tools, among which an important place is occupied by legal instruments (Kulovesi \& Oberthuer, 2020) of state and public regulation related to planning (national medium and long-term energy and climate plans should be in line with the EU strategy), monitoring (it is necessary to control the accuracy of pollution measurement, the process of transferring environmental assessment data, and the level of ambition to reduce greenhouse gas emissions), reporting (annual reports on greenhouse gas emissions, universalization of the EU reporting system), transparency and an inclusive approach to public participation in dialogue on climate and energy.

Howarth and Roberts (2018) summarized the energy efficiency barriers that hindered the suc- 
cessful implementation of the UK Green Deal. Developed in the plane of the Ukrainian economy, bearing in mind its specifics, they can play the role of a warning against mistakes in energy management when Ukraine joins the European Green Deal. The most serious barriers are:

- The relative availability of financial investment, which affects both the willingness to pay and the cheapening, and therefore lower quality environmental and energy innovations.

- Subjectivity in determining the effectiveness of measures, which usually translates into underestimation of benefits, in particular, in terms of environmental, social and aesthetic benefits. Time is one of the factors of negative subjective evaluation: costs are felt immediately, and most of the result occurs in the future. In addition to the low tangibility of future benefits, there is also a risk associated with the instability of global and national socio-economic processes.

- Awareness of the target group: just information about the effectiveness of measures is not enough, systematic information work and effective communication policy aimed at persuading with strong arguments are also needed.

- Contradiction between the national and European regulatory framework, as well as the inertia of the regulatory bodies in the transformation period of the introduction of environmental and energy innovations.

- Difference in motivation caused by property rights: the willingness to spend on environmentally and energy-innovative activities of owners and tenants differs significantly. For the most part, only the owner is the interested party.

- Mentality and its manifestation through social norms and stereotypes that hinder innovation and borrowing from other cultures. Also significant is the existing distrust of a large part of the population to the actions of the authorities in Ukraine.

The integration of national environmental policies into the EGD is a very complex and contro- versial issue. Since 2019, the EU has been pursuing protectionist policies through the EGD with the support of green parties in the European Parliament. New environmental standards are too strict for developing countries. EU climate policy should not be based solely on the predominance of economic and social development in its countries compared to less developed countries (Bochkarev, 2020). The EGD should motivate joint action in the field of nature management and environmental protection at the international level. An important step for the EU is a balanced approach in negotiating with each country on the export-import of products, the production or consumption of which has a significant impact on the environment.

According to the recommendations of Fuchs et al. (2020) on adjusting the EU policy within the EGD, taking into account the environmental safety factor (Gryshchenko et al., 2015), Ukraine, for its part, should take the following steps:

- gradually bring national environmental standards in line with EU standards, especially in the agricultural sector, and strengthen measures for product quality monitoring and customs control (when carrying out export-import operations with the EU and other countries);

- reduce in the future the share of bioenergy production in the structure of renewable energy in order to reduce the burden on agriculture, preventing increased deforestation and promoting mass planting of trees and landscaping of urban areas.

In this case, the following should be considered: the relationship between climate change policy and prospects for urban and agricultural development, trends in the digital economy and legal barriers in the EU (EuroMemo Group, 2019), a set of opportunities and threats for Ukraine within the EGD (IRF, 2020), measures aimed at reducing waste generation, in particular plastics, planning a circular economy (Kumar, 2020; Qu et al., 2020; Shevchenko \& Kronenberg, 2020), strengthening regulatory mechanisms (Oxford Analytica, 2020), an inclusive approach to social and economic development (Petrushenko et al., 2019). 
Considering the specifics of governance within the European Green Deal when prioritizing the relationship between the SDGs and the EGD provisions (Figure 1) will increase the realism of their implementation in Ukraine based on sustainability and inclusiveness. Based on the results of the quantitative assessment of readiness for change (the left part of Figure 1 and Table A1), strong management support is needed, first of all, for the implementation of the following goals: climate change, sustainability of terrestrial ecosystems and sustainable cities and communities (accordingly, the following EGD provisions: growth of climate ambitions, ecosystem protection, energy-efficient and resource-saving construction). At the same time, the areas that meet the goals of fighting

Source: Developed by the authors based on European Commission (2020) and United Nations (2020a).

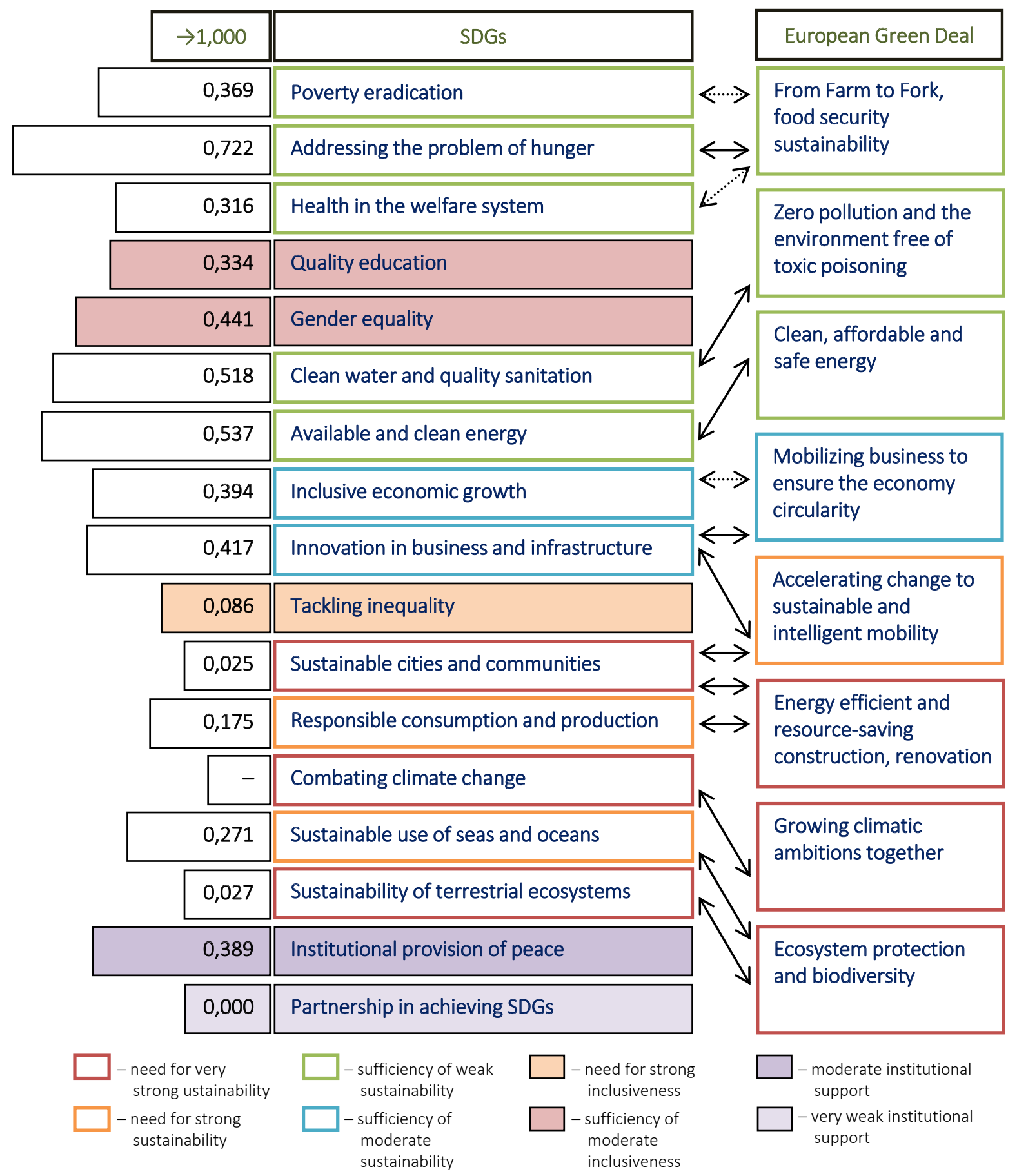

Figure 1. Priority of linkages between SDGs and EGD provisions 
hunger, affordable and clean energy, clean water and quality sanitation have the greatest readiness for change and, therefore, the greatest investment attractiveness (accordingly, the following EGD provisions: food security, clean and safe energy, zero pollution).

Among the SDGs that reflect more social than economic and environmental aspects and therefore have no direct link to the EU green initiative, tackling inequality requires significant governance efforts. Partnership in achieving the SDGs also needs strong institutional support.

The results of the study of the management features within the EGD and the assessment of readiness for change within the SDGs are the basis for creating a target program for the development of Ukrainian-European cooperation «European integration green transformation of the Ukrainian economy for a sustainable future in 2030 and 2050» (the format of the sectoral areas proposed under the program corresponds to the areas of research within Horizon 2020 (Publications Office of the European Union, 2020). The purpose of the program is to substantiate and develop a conceptual model and mechanisms for transforming the national economy in accordance with the European Green Deal, in the face of overcoming the consequences of climate and pandemic crises and taking into account geopolitical factors, on the way to European integration for a sustainable future in 2030 and 2050 in Ukraine.

To achieve this goal, it is necessary to solve the following tasks:

- to develop a concept for a green transition of the national economy to a climate-neutral economy;

- to reveal theoretical and methodological foundations and carry out a multivariate analysis of Ukraine's state policy in the field of climate change;

- to substantiate and develop transformation scenarios for the development of the Ukrainian economy in accordance with the EGD for the forecast periods of 2030 and 2050; to develop tools for organizational and economic support for innovative onshore and offshore renewable energy technologies and their integration into the energy system as part of accelerating the green transition and Ukraine's clean energy partnership with the EU;

to justify and improve systemic solutions for the territorial deployment of a circular economy and closing the industrial carbon cycle to combat climate change;

- to form theoretical and methodological bases for the development of green airports and ports as multimodal nodes for sustainable and smart mobility in Ukraine in accordance with the European Green Deal;

- to propose methodological approaches to the formation of systemic economic innovations for sustainable nutrition according to the From Farm to Fork principle in Ukraine in accordance with the European Green Deal;

to improve the theoretical-methodological and scientific-methodological bases for the restoration of biodiversity and ecosystem services in Ukraine in accordance with the European Green Deal;

- to propose methodological approaches to the organizational and economic support for systemic innovative solutions for zero pollution to protect the health, environment and natural resources of Ukraine;

- to substantiate and develop an economic and legal mechanism for transforming Ukraine's economy in accordance with the European Green Deal;

- to substantiate and develop market and state mechanisms for transforming Ukraine's economy in accordance with the European Green Deal;

- to develop a strategy for green transformation of socio-economic processes in Ukraine to achieve climate neutrality. 
The European Green Deal is an integral part of the European Commission's strategy to implement the UN 2030 Agenda and the Sustainable Development Goals. Consequently, sustainability and citizen well-being are central to the design of a new EU green political and economic course.

The program provides for a thorough analysis of Ukrainian, European and global trends in climate change and relevant sustainable development policies, the use of statistics, continuous monitoring of indicators that characterize the dynamics of socio-economic, environmental, and demographic status of the state and regions in connection with climate change, generalization of foreign and domestic experience in a climate-neutral economy, green energy, European integration processes, etc. The program is interdisciplinary in nature, which allows you to get a comprehensive vision and provide a systematic solution to the problem of transforming the national economy in accordance with the European Green Deal.

\section{DISCUSSION}

The launch of the ambitious EGD policy has coincided with a real challenge for humanity and international politics, such as COVID-19. The situation during the coronavirus pandemic makes people think about the consequences of not only this, but any global crisis: "saving lives and livelihoods requires urgent action to address both the pandemic and the climate emergency" (United Nations, 2020). In a positive scenario, countries recovering from the coronavirus pandemic will, by inertia, implement reforms to protect human rights in the context of the green resolution: decarbonization of the economy, sustainable inclusive growth, international cooperation on the implementation of "the polluter pays" principle, and increasing the volume and equitable distribution of green investment.

According to Huber (2020), the global coronavirus situation can be used to rethink the role of politics in solving environmental challenges. The European Green Deal pursues the ambitious goal of the EU's global leadership in climate neutralization, which can be seen as separating from global environmental concerns. However, this approach, on the contrary, contributes to solving not only environmental, but also any geopolitical challenges at the global level. Consequently, the framework for the implementation of the European Green Deal is not limited to EU countries or even other European countries, they can always be extended for cooperation with any country or international organization.

The EDG could be a green response to the COVID-19 crisis (Smith, 2020). However, even in a situation requiring concerted action at the global level, there are significant differences in the vision and implementation of environmental policy between world leaders such as the United States and the European Union. The new green policy on all continents should be a global tool for achieving sustainability and equality, regardless of the level of economic development or any other differences between countries (Stainforth et al., 2019).

\section{CONCLUSION}

Using the example of Ukraine, this paper defines the country's readiness for change as an indicator of its managerial capacity for the implementation of the Sustainable Development Goals in accordance with the EGD provisions: the highest value of the integrated change readiness index corresponds to Goal 2 "Addressing the problem of hunger", and the lowest - to Goal 13 "Combating climate change". The priority of the relationship between the SDGs and the EGD provisions on the «the need for very strong sustainability - the sufficiency of weak sustainability» continuum is established: the closest thing to the EU indicators is the EGD position "Sustainable food security through the From Farm to Fork policy", the least close is the "Growing climate ambition together" position. Accordingly, to improve Ukraine's chances of successfully completing the European integration process by 2030, governance efforts should focus on combating climate change and protecting ecosystems and biodiversity. Based on the identified quantitative results of readiness for change, as well as the specifics of management within the EGD, the provisions of the target program for the development of Ukrainian-European cooperation with the 
pilot name «European integration green transformation of the Ukrainian economy for a sustainable future in 2030 and 2050» were developed. The proposed program includes: scenarios for Ukraine's transition to a climate-neutral economy in accordance with the European Green Deal (the concept of a climate-neutral economy, the growth of climate ambitions in the context of cross-sectoral challenges, overcoming the inertia of society and economy on the way to the EGD); transformative changes in sustainable development policies in the areas identified in the European Green Deal (clean, affordable and safe energy, zero pollution, industry for clean and circular economy, sustainable and smart mobility, sustainable food From Farm to Fork, biodiversity and ecosystems); levers and tools of mechanisms for European integration green transformation of the Ukrainian economy (economic, legal, market and state mechanisms, regulation and standardization, investment and innovation, national reforms, dialogue with social partners, international cooperation).

\section{AUTHOR CONTRIBUTIONS}

Conceptualization: Hanna Shevchenko, Mykola Petrushenko, Borys Burkynskyi.

Data curation: Mykola Petrushenko.

Formal analysis: Hanna Shevchenko, Nina Khumarova.

Funding acquisition: Hanna Shevchenko.

Investigation: Hanna Shevchenko, Mykola Petrushenko.

Methodology: Hanna Shevchenko, Mykola Petrushenko, Nina Khumarova.

Project administration: Hanna Shevchenko, Borys Burkynskyi.

Resources: Borys Burkynskyi, Nina Khumarova.

Software: Nina Khumarova.

Supervision: Hanna Shevchenko, Borys Burkynskyi, Nina Khumarova.

Validation: Hanna Shevchenko.

Visualization: Borys Burkynskyi, Nina Khumarova.

Writing - original draft: Hanna Shevchenko, Mykola Petrushenko.

Writing - review \& editing: Mykola Petrushenko.

\section{ACKNOWLEDGMENT}

The paper contains the results of research conducted under the President of Ukraine's grant Formation and Use of Natural-Resource Assets of the Recreational and Tourism Sphere (0120U100159).

\section{REFERENCES}

1. Bochkarev, D. (2020, September). The European Green Deal: Saving the Planet or Protecting the Markets? IAI Commentaries, 20/60, 5 p. Retrieved from https://www.iai.it/ en/pubblicazioni/european-greendeal-saving-planet-or-protectingmarkets

2. de Oliveira, D. P. S., Ferreira, M. J., Sadeghi, M., Arvanitidis, N., Decrée, S., Gautneb, H., Gloaguen, E., Törmänen, T., Reginiussen, H., Sievers, H., Quental, L. Q., \& Wittenberg, A. (2020). FRAME's (Forecasting and Assessing Europe's Strategic Raw Materials Needs) contribution to the "Euro- pean Green Deal". EGU General Assembly, EGU2020-5950. https:// doi.org/10.5194/egusphereegu2020-5950

3. EuroMemo Group. (2019). A Green New Deal for Europe - Opportunities and challenges. Euro Memorandum 2020. Retrieved from http://www2.euromemorandum.eu/uploads/euromemorandum_2020.pdf

4. European Commission. (2020). A European Green Deal. The European Commission's priorities. Retrieved from https:// ec.europa.eu/info/strategy/priori- ties-2019-2024/european-greendeal_en

5. Eurostat. (2020). Sustainable development in the European Union. Monitoring report on progress towards the SDGs in an EU context. Retrieved from https:// ec.europa.eu/eurostat/documents/3217494/11011074/KS-0220-202-EN-N.pdf/334a8cfe-636abb8a-294a-73a052882f7f

6. Evans, S., Mehling, M., Ritz, R., \& Sammon, P. (2020). Border carbon adjustments and industrial competitiveness in a European Green Deal. Cambridge Working 
Papers in Economics, 2036, 16 p. Retrieved from http://www.econ. cam.ac.uk/research-files/repec/ cam/pdf/cwpe2036.pdf

7. Friedman, L. (2019, February 21). What is the Green New Deal? A climate proposal, explained. The New York Times. Retrieved from https://www.nytimes. com/2019/02/21/climate/greennew-deal-questions-answers.html

8. Fuchs, R., Brown, C., \& Rounsevell, M. (2020). Europe's Green Deal offshores environmental damage to other nations. $\mathrm{Na}$ ture, 586, 671-673. https://doi. org/10.1038/d41586-020-02991-1

9. Government of Ukraine. (2020, February 20). Dmytro Kuleba will officially submit Ukraine's proposal to participate in European Green Deal to the European Union. Government Portal. Official website. Retrieved from https://www.kmu.gov.ua/ en/news/dmitro-kuleba-oficijnonapravit-yes-propoziciyi-ukrayinishchodo-uchasti-v-yevropejskijzelenij-ugodi

10. Gryshchenko, V. F., Dreval, O. Y., \& Gryshchenko, I. V. (2015). Regional export-import potential use management within the system of ecological and economic security. Actual Problems in Economics, 170, 226-238. Retrieved from https:// www.researchgate.net/publication/298697867_Regional_exportimport_potential_use_management_within_the_system_of_ecological_and_economic_security

11. Haines, A., \& Scheelbeek, P. (2020). European Green Deal: a major opportunity for health improvement. The Lancet, 395(10233). https:// doi.org/10.1016/S01406736(20)30109-4

12. Hainsch, K., Göke, L., Kemfert, C., Oei, P.-Y., \& von Hirschhausen, C. (2020). European Green Deal: Using ambitious climate targets and renewable energy to climb out of the economic crisis. DIW Weekly Report. 28+29. DIW Berlin - Deutsches Institut für Wirtschaftsforschung, 10, 304-310. https://doi. org/10.18723/diw_dwr:2020-28-1

13. Howarth, C., \& Roberts, B. M. (2018). The Role of the UK Green
Deal in shaping pro-environmental behaviours: Insights from two case studies. Sustainability, 10(6), 2107. https://doi.org/10.3390/ su10062107

14. Huber, D. (2020, April). The New European Commission's Green Deal and geopolitical language: A critique from a decentring perspective. IAI Papers, 20/06. Retrieved from https://www.iai.it/ sites/default/files/iaip2006.pdf

15. Ikerd, J. (2019). The economic pamphleteer: A "Green New Deal" for farm and food policy. Journal of Agriculture, Food Systems, and Community Development, 9(1), 3-5. https://doi.org/10.5304/jafscd.2019.091.008

16. IRF. (2020, April). European Green Deal: opportunities and threats for Ukraine. Analytical paper, 74 p. Retrieved from https://www.irf.ua/wp-content/ uploads/2020/06/european-greendealwebfinal.pdf

17. KPMG International Cooperative. (2019). 2019 Change Readiness Index. Retrieved from https://assets.kpmg/content/dam/kpmg/xx/ pdf/2019/06/change-readinessindex-report-2019.pdf

18. Kulovesi, K., \& Oberthür, S. (2020). Assessing the EU's 2030 climate and energy policy framework: Incremental change toward radical transformation? Review of European, Comparative \& International Environmental Law, 29(2), 151-166. https://doi.org/10.1111/ reel. 12358

19. Kumar, P. (2020). Reduce, reuse, recycle. Plastic and packaging waste in the European Green Deal and Circular Economy Action Plan. IASS Discussion Paper, 5 p. https://doi.org/10.2312/ iass. 2020.014

20. Li, X. (2014). Scientific development and a new green deal. China Finance and Economic Review, 2, 2, 8 p. https://doi.org/10.1186/21965633-2-2

21. Lucchese, M., \& Pianta, M. (2020). Europe's alternative: a Green Industrial Policy for sustainability and convergence. MPRA Paper, 98705. Retrieved from https://mpra.ub.uni-muenchen. de/98705/1/MPRA_paper_98705. pdf

22. Matvieieva, Y., Myroshnychenko, I., \& Valenkevych, L. (2019). Optimization model of the socio-ecological-economic development of the administrative territory. Journal of Environmental Management and Tourism, 10(8), 1874-1899. Retrieved from https://journals. aserspublishing.eu/jemt/article/ view/4405

23. Montanarella, L., \& Panagos, P. (2021). The relevance of sustainable soil management within the European Green Deal. Land Use Policy, 100, 104950. https:// doi.org/10.1016/j.landusepol.2020.104950

24. OECD. (2020). OECD Monitoring of the Energy Strategy of Ukraine until 2035, 69 p. Retrieved from https://www.oecd.org/eurasia/ competitiveness-programme/ eastern-partners/Monitoringthe-energy-strategy-Ukraine2035-EN-.pdf

25. Ossewaarde, M., \& OssewaardeLowtoo, R. (2020). The EU's Green Deal: A third alternative to green growth and degrowth? Sustainability, 12(23), 9825. https://doi. org/10.3390/su12239825

26. Oxford Analytica. (2020). EU Green Deal will involve greater state regulation. Expert Briefings. https://doi.org/10.1108/OXANDB252161

27. Pastukhova, M., Pepe, J. M., \& Westphal, K. (2020). Beyond the Green Deal: Upgrading the EU's energy diplomacy for a new era. SWP Comment, C 31, 8 p. https:// doi.org/10.18449/2020C31

28. Petrushenko, M., Shevchenko, H., Burkynskyi, B., \& Khumarova, N. (2019). A game-theoretical model for investment in inclusive recreation and wellness in Ukraine: the regional context. Investment Management and Financial Innovations, 16(4), 382-394. http://dx.doi. org/10.21511/imfi.16(4).2019.32

29. Pettifor, H., Wilson, C., \& Chryssochoidis, G. (2015). The appeal of the green deal: Empirical evidence for the influence of energy ef- 
ficiency policy on renovating homeowners. Energy Policy, 79, 161-176. https://doi.org/10.1016/j. enpol.2015.01.015

30. Pianta, M., \& Lucchese, M. (2020). Rethinking the European Green Deal: An industrial policy for a just transition in Europe. Review of Radical Political Economics, 52(4), 633-641. https://doi. org/10.1177/0486613420938207

31. Publications Office of the European Union. (2020, September). Horizon 2020. European Green Deal call. Retrieved from https:// op.europa.eu/en/publication-detail/-/publication/cc10c455-f98c11ea-b44f-01aa75ed71a1/

32. Qu, D., Shevchenko, T., \& Yan, X. (2020). University curriculum education activities towards circular economy implementation. International Journal of Scientific \& Technology Research, 9(5), 200206. Retrieved from http://www. ijstr.org/final-print/may2020/ University-Curriculum-Education-Activities-Towards-CircularEconomy-Implementation.pdf

33. Rosenow, J., \& Eyre, N. (2016). A post mortem of the Green Deal: Austerity, energy efficiency, and failure in British energy policy. Energy Research \& Social Science, 21, 141-144. https://doi. org/10.1016/j.erss.2016.07.005

34. Schiermeier, Q. (2020). EU champions bold new climate law. Nature. News. https://doi. org/10.1038/d41586-020-00647-8

35. Seitz, R. Z., \& Krutka, D. G. (2020). Can the Green New Deal save us? An interdisciplinary inquiry. The Social Studies, 111(2), 74-85. https://doi.org/10.1080/003 77996.2019 .1677547

36. Shevchenko, H., Petrushenko, M., Burkynskyi, B., Khumarova, N., \& Opanasiuk, Y. (2020). Management of wellness and recreation in urban agglomerations. Problems and Perspectives in Management, 18(1), 231-241. http://dx.doi. org/10.21511/ppm.18(1).2020.20

37. Shevchenko, T., \& Kronenberg, J., (2020). Management of material and product circularity potential as an approach to operationalise circular economy. Progress in Industrial Ecology, An International Journal, 14(1), 30-57. https://doi. org/10.1504/PIE.2020.105193

38. Siddi, M. (2020, May). The European Green Deal: Assessing its current state and future implementation. FIIA Working Paper, 114. Retrieved from https://www.researchgate.net/ publication/341701815_The_European_Green_Deal_Assessing_its_current_state_and_future_implementation

39. Sikora, A. (2020, November 03). European Green Deal - legal and financial challenges of the climate change. ERA Forum. https://doi. org/10.1007/s12027-020-00637-3

40. Smith, D. C. (2020). 'Green responses' to COVID-19: Europe and the United States diverge yet again. Journal of Energy \& Natural Resources Law, 38(3), 209-212. https://doi.org/10.1080/02646811. 2020.1785766

41. Stainforth, T., Charveriat, C., Bodin, E., \& Filipova, T. (2019, April). Green Deal for all. Policy Report. FEPS, IEEP, Brussels, 29 p. Retrieved from https://www. feps-europe.eu/attachments/publications/green $\% 20$ deal $\% 20$ for $\% 20$ all\%20-\%20final\%20pp.pdf

42. Storm, S. (2020). The EU's Green Deal: Bismarck's 'What is possible' versus Thunberg's 'What is imperative'. Institute for New Economic Thinking. Working Paper, 117. https://doi.org/10.36687/ inetwp117

43. Sustainable Development Goals: Ukraine. (2020). Voluntary National Review. Retrieved from https://sustainabledevelopment.un.org/content/ documents/26295VNR_2020_ Ukraine_Report.pdf

44. Suttor-Sorel, L., Godinot, S., Bodin, O., Jourdan, S., Puisieux, K., \& ten Brink, P. (2019, September). Game-changer: Financing the European Green Deal. $A$ civil society briefing on financing a fair ecological transition, 15 p. Retrieved from https://www. finance-watch.org/wp-content/up-
loads/2019/09/Financing-the-European-Green-Deal_Sept2019_03. pdf

45. United Nations. (2019). The Sustainable Development Goals Report. Retrieved from https:// unstats.un.org/sdgs/report/2019/ The-Sustainable-DevelopmentGoals-Report-2019.pdf

46. United Nations. (2020). Goal 13: Take urgent action to combat climate change and its impacts. Sustainable Development Goals. Retrieved from https://www. un.org/sustainabledevelopment/ climate-change/

47. United Nations. (2020a). The 17 Goals. Department of Economic and Social Affairs. Retrieved from https://sdgs.un.org/goals 


\section{APPENDIX A}

Table A1. Calculation of the integral change readiness indicator in accordance with the SDGs in Ukraine

Source: Calculated by the authors based on Sustainable Development Goals: Ukraine (2020).

\begin{tabular}{|c|c|c|c|c|c|c|c|c|c|c|c|c|c|}
\hline $\begin{array}{l}\text { ஸ̆ } \\
\text { صิ }\end{array}$ & & 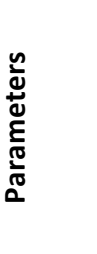 & 뭉 & 웅 & 을 & 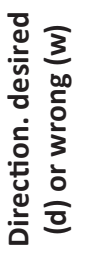 & 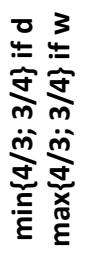 & 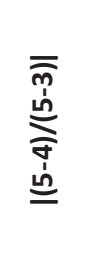 & 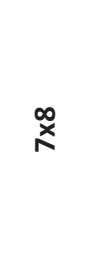 & $\begin{array}{l}\text { a } \\
\underline{\underline{ }}\end{array}$ & $\begin{array}{l}\frac{n}{20} \\
\frac{000}{3} \\
3\end{array}$ & 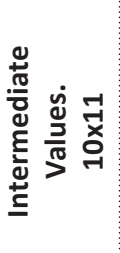 & 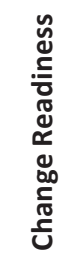 \\
\hline \multirow{5}{*}{1} & \multirow{2}{*}{1.1} & 1.1 .1 & 58.3 & 43.2 & 15.0 & $\downarrow d$ & 0.741 & 0.651 & 0.482 & -0.730 & $1 / 6$ & -0.122 & \\
\hline & & 1.1 .2 & 2.4 & 1.8 & 0.0 & $\downarrow d$ & 0.750 & 0.750 & 0.563 & -0.574 & $1 / 6$ & -0.096 & \\
\hline & 1.2 & 1.2 .1 & 63.0 & 70.9 & 85.0 & $\uparrow d$ & 0.889 & 0.641 & 0.570 & -0.562 & $1 / 3$ & -0.187 & \\
\hline & \multirow{2}{*}{1.3} & 1.3 .1 & 1.5 & 1.5 & 1.27 & $\uparrow w$ & 1.000 & 1.000 & 1.000 & 0.000 & $1 / 6$ & 0.000 & \\
\hline & & 1.3 .2 & 54.6 & 49.4 & 30.0 & $\downarrow d$ & 0.905 & 0.789 & 0.714 & -0.337 & $1 / 6$ & -0.056 & 0.369 \\
\hline \multirow{9}{*}{2} & \multirow{3}{*}{2.1} & 2.1 .1 & 50.9 & 52.8 & 80.0 & $\uparrow d$ & 0.964 & 0.935 & 0.901 & -0.104 & $1 / 12$ & -0.009 & \\
\hline & & 2.1 .2 & 209.9 & 197.7 & 380.0 & $\downarrow w$ & 1.062 & 1.072 & 1.138 & 0.129 & $1 / 12$ & 0.011 & \\
\hline & & 2.1 .5 & 50.9 & 57.8 & 90.0 & $\uparrow d$ & 0.881 & 0.824 & 0.726 & -0.320 & $1 / 12$ & -0.027 & \\
\hline & \multirow{2}{*}{2.2} & 2.2 .1 & 8.68 & 10.89 & 15.00 & $\uparrow d$ & 0.797 & 0.650 & 0.518 & -0.658 & $1 / 8$ & -0.082 & \\
\hline & & 2.2 .2 & 95.2 & 101.1 & 102.0 & $\uparrow d$ & 0.942 & 0.132 & 0.124 & -2.087 & $1 / 8$ & -0.261 & \\
\hline & \multirow{3}{*}{2.3} & 2.3 .1 & 88.6 & 103.9 & 103 & $\uparrow d$ & 0.853 & 0.063 & 0.054 & -2.919 & $1 / 12$ & -0.243 & \\
\hline & & 2.3 .2 & 38.3 & 44.3 & 65.0 & $\uparrow d$ & 0.865 & 0.775 & 0.670 & -0.400 & $1 / 12$ & -0.033 & \\
\hline & & 2.3 .3 & 1.0 & 0.72 & 1.70 & $\downarrow w$ & 1.389 & 1.4 & 1.945 & 0.665 & $1 / 12$ & 0.055 & \\
\hline & 2.4 & 2.4 .1 & 144.4 & 108.3 & 105.0 & $\downarrow d$ & 0.75 & 0.084 & 0.063 & -2.765 & $1 / 4$ & -0.691 & 0.722 \\
\hline \multirow{14}{*}{3} & 3.1 & 3.1 .1 & 15.1 & 12.5 & 11.2 & $\downarrow d$ & 0.828 & 0.333 & 0.276 & -1.287 & $1 / 8$ & -0.161 & \\
\hline & 3.2 & 3.2 .1 & 9.3 & 8.3 & 6.5 & $\downarrow d$ & 0.892 & 0.643 & 0.573 & -0.556 & $1 / 8$ & -0.070 & \\
\hline & \multirow{2}{*}{3.3} & 3.3 .1 & 37.0 & 42.8 & 20.6 & $\uparrow w$ & 1.157 & 1.354 & 1.566 & 0.449 & $1 / 16$ & 0.028 & \\
\hline & & 3.3 .2 & 55.9 & 50.5 & 32.9 & $\downarrow d$ & 0.903 & 0.765 & 0.691 & -0.370 & $1 / 16$ & -0.023 & \\
\hline & \multirow{4}{*}{3.4} & 3.4 .1 & 64.0 & 62.1 & 45.0 & $\downarrow d$ & 0.970 & 0.900 & 0.873 & -0.136 & $1 / 32$ & -0.004 & \\
\hline & & 3.4 .2 & 28.9 & 25.5 & 22.0 & $\downarrow d$ & 0.882 & 0.507 & 0.447 & -0.804 & $1 / 32$ & -0.025 & \\
\hline & & 3.4 .3 & 26.3 & 24.1 & 18.3 & $\downarrow d$ & 0.916 & 0.725 & 0.664 & -0.409 & $1 / 32$ & -0.013 & \\
\hline & & 3.4 .4 & 12.2 & 11.5 & 9.5 & $\downarrow d$ & 0.943 & 0.741 & 0.699 & -0.359 & $1 / 32$ & -0.011 & \\
\hline & \multirow{2}{*}{3.5} & 3.5 .1 & 0.38943 & 0.38675 & 0.29000 & $\downarrow d$ & 0.993 & 0.973 & 0.966 & -0.034 & $1 / 16$ & -0.002 & \\
\hline & & 3.5 .2 & 0.15514 & 0.15010 & 0.13000 & $\downarrow d$ & 0.968 & 0.800 & 0.774 & -0.256 & $1 / 16$ & -0.016 & \\
\hline & 3.6 & 3.6 .1 & 12.6 & 10.5 & 9.5 & $\downarrow d$ & 0.833 & 0.323 & 0.269 & -1.314 & $1 / 8$ & -0.164 & \\
\hline & 38 & 3.8 .1 & 5.0 & 7.5 & 4.0 & $\uparrow w$ & 1.500 & 3.500 & 5.250 & 1.658 & $1 / 16$ & 0.104 & \\
\hline & 3.0 & 3.8 .2 & 31.4 & 29.3 & 20.0 & $\downarrow d$ & 0.933 & 0.816 & 0.761 & -0.273 & $1 / 16$ & -0.017 & \\
\hline & 3.9 & 3.9 .1 & 48.78 & 48.24 & 30.0 & $\downarrow d$ & 0.989 & 0.971 & 0.961 & -0.040 & $1 / 8$ & -0.005 & 0.316 \\
\hline \multirow{6}{*}{4} & 4.2 & 4.2 .1 & 70.6 & 69.1 & 95.0 & $\downarrow w$ & 1.022 & 1.061 & 1.085 & 0.081 & $1 / 4$ & 0.020 & \\
\hline & \multirow{2}{*}{4.5} & 4.5 .1 & 9.2 & 8.6 & 14.0 & $\downarrow w$ & 1.070 & 1.125 & 1.204 & 0.185 & $1 / 8$ & 0.023 & \\
\hline & & 4.5 .2 & 48.9 & 62.6 & 80.0 & $\uparrow d$ & 0.781 & 0.559 & 0.437 & -0.828 & $1 / 8$ & -0.103 & \\
\hline & 4.6 & 4.6 .1 & 14.79 & 13.04 & 25.0 & $\downarrow w$ & 1.134 & 1.171 & 1.328 & 0.284 & $1 / 4$ & 0.071 & \\
\hline & 47 & 4.7.1 & 85.9 & 95.2 & 95.0 & $\uparrow d$ & 0.902 & 0.022 & 0.020 & -3.921 & $1 / 8$ & -0.490 & \\
\hline & 4.7 & 4.7 .2 & 72.3 & 98.7 & 80.0 & $\uparrow d$ & 0.733 & 2.429 & 1.780 & 0.577 & $1 / 8$ & 0.072 & 0.334 \\
\hline \multirow{4}{*}{5} & \multirow{2}{*}{5.4} & 5.4 .1 & 12.0 & 20.0 & 30.0 & $\uparrow d$ & 0.600 & 0.556 & 0.333 & -1.099 & $1 / 6$ & -0.183 & \\
\hline & & 5.4 .2 & 25.0 & 25.0 & 30.0 & $\uparrow d$ & 1.000 & 1.000 & 1.000 & 0.000 & $1 / 6$ & 0.000 & \\
\hline & 5.5 & 5.5 .1 & 27.3 & 19.7 & 10.0 & $\downarrow d$ & 0.722 & 0.561 & 0.405 & -0.904 & $1 / 3$ & -0.301 & \\
\hline & 5.6 & 5.6 .1 & 74.9 & 77.2 & 85.0 & $\uparrow d$ & 0.970 & 0.772 & 0.749 & -0.289 & $1 / 3$ & -0.096 & 0.441 \\
\hline \multirow{7}{*}{6} & \multirow{2}{*}{6.1} & 6.1 .4 & 25.0 & 30.1 & 50.0 & $\uparrow d$ & 0.831 & 0.796 & 0.661 & -0.413 & $1 / 8$ & -0.052 & \\
\hline & & 6.1 .5 & 99.0 & 99.2 & 100.0 & $\uparrow d$ & 0.998 & 0.800 & 0.798 & -0.225 & $1 / 8$ & -0.028 & \\
\hline & 6.2 & 6.2 .2 & 92.0 & 96.1 & 100.0 & $\uparrow d$ & 0.957 & 0.488 & 0.467 & -0.762 & $1 / 4$ & -0.191 & \\
\hline & \multirow{2}{*}{6.3} & 6.3 .1 & 875.1 & 737.2 & 279.0 & $\downarrow d$ & 0.842 & 0.769 & 0.647 & -0.435 & $1 / 8$ & -0.054 & \\
\hline & & 6.3 .2 & 16.38 & 13.72 & 5.00 & $\downarrow d$ & 0.838 & 0.766 & 0.642 & -0.443 & $1 / 8$ & -0.055 & \\
\hline & \multirow{2}{*}{6.4} & 6.4 .1 & 23.86 & 10.30 & 2.50 & $\downarrow d$ & 0.432 & 0.365 & 0.158 & -1.847 & $1 / 8$ & -0.231 & \\
\hline & & 6.4 .2 & 100.00 & 43.19 & 70.00 & $\downarrow d$ & 0.432 & 0.894 & 0.386 & -0.952 & $1 / 8$ & -0.119 & 0.518 \\
\hline
\end{tabular}


Table A1 (cont.). Calculation of the integral change readiness indicator in accordance with the SDGs in Ukraine

\begin{tabular}{|c|c|c|c|c|c|c|c|c|c|c|c|c|c|}
\hline 号 & & 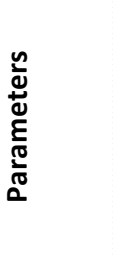 & 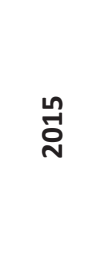 & 윰 & ஜ्లి & 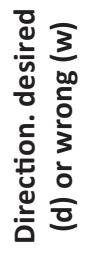 & 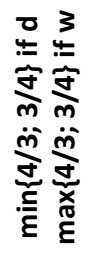 & 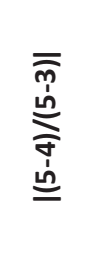 & $\underset{\sim}{\infty}$ & $\begin{array}{l}\underline{a} \\
\underline{a}\end{array}$ & $\begin{array}{l}\frac{n}{\frac{5}{000}} \\
\frac{0}{3}\end{array}$ & 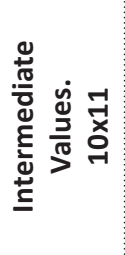 & 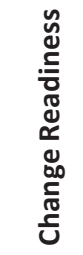 \\
\hline \multirow{5}{*}{7} & \multirow{2}{*}{7.1} & 7.1.1 & 157.7 & 154.0 & 182.0 & $\downarrow w$ & 1.024 & 1.152 & 1.180 & 0.165 & $1 / 8$ & 0.021 & \\
\hline & & 7.1 .2 & 11.5 & 11.8 & 9.0 & $\uparrow w$ & 1.026 & 1.120 & 1.149 & 0.139 & $1 / 8$ & 0.017 & \\
\hline & 7.2 & 7.2 .2 & 91.6 & 55.4 & 50.0 & $\downarrow d$ & 0.605 & 0.130 & 0.079 & -2.544 & $1 / 4$ & -0.636 & \\
\hline & 7.3 & 7.3 .1 & 4.9 & 7.0 & 17.1 & $\uparrow d$ & 0.7 & 0.828 & 0.580 & -0.546 & $1 / 4$ & -0.136 & \\
\hline & 7.4 & 7.4.1 & 0.282 & 0.269 & 0.140 & $\downarrow d$ & 0.954 & 0.908 & 0.867 & -0.143 & $1 / 4$ & -0.036 & 0.537 \\
\hline \multirow{13}{*}{8} & \multirow{4}{*}{8.1} & 8.1 .1 & 90.2 & 103.2 & 107.0 & $\uparrow d$ & 0.874 & 0.226 & 0.198 & -1.621 & $1 / 24$ & -0.068 & \\
\hline & & 8.1 .2 & 13.5 & 18.0 & 22.0 & $\uparrow d$ & 0.75 & 0.471 & 0.353 & -1.041 & $1 / 24$ & -0.043 & \\
\hline & & 8.1 .3 & 19.2 & 16.4 & 30.0 & $\downarrow w$ & 1.171 & 1.259 & 1.475 & 0.388 & $1 / 24$ & 0.016 & \\
\hline & & 8.1 .4 & 64 & 47 & 40.0 & $\downarrow d$ & 0.734 & 0.292 & 0.214 & -1.541 & $1 / 24$ & -0.064 & \\
\hline & \multirow{2}{*}{8.2} & 8.2 .1 & 0.1194 & 0.1204 & 0.2300 & $\uparrow d$ & 0.992 & 0.991 & 0.983 & -0.017 & $1 / 12$ & -0.001 & \\
\hline & & 8.2 .2 & 99.2 & 101.9 & 105.8 & $\uparrow d$ & 0.974 & 0.591 & 0.576 & -0.552 & $1 / 12$ & -0.046 & \\
\hline & 8.3 & 8.3 .1 & 64.4 & 66.9 & 70.0 & $\uparrow d$ & 0.963 & 0.554 & 0.533 & -0.629 & $1 / 6$ & -0.105 & \\
\hline & 8.4 & 8.4 .1 & 17.2 & 14.5 & 15.5 & $\downarrow d$ & 0.843 & 0.588 & 0.496 & -0.701 & $1 / 6$ & -0.117 & \\
\hline & \multirow{2}{*}{8} & 8.5 .1 & 100 & 91 & 55 & $\downarrow d$ & 0.91 & 0.800 & 0.728 & -0.317 & $1 / 12$ & -0.026 & \\
\hline & & 8.5 .2 & 100 & 113 & 45 & $\uparrow w$ & 1.13 & 1.236 & 1.397 & 0.334 & $1 / 12$ & 0.028 & \\
\hline & \multirow{3}{*}{8.6} & 8.6 .1 & 6.5 & 7.0 & 10.5 & $\uparrow d$ & 0.929 & 0.875 & 0.813 & -0.207 & $1 / 18$ & -0.012 & \\
\hline & & 8.6 .2 & 58.1 & 64.3 & 80.0 & $\uparrow d$ & 0.804 & 0.717 & 0.576 & -0.551 & $1 / 18$ & -0.031 & \\
\hline & & 8.6 .3 & 81 & 64 & 20 & $\downarrow d$ & 0.790 & 0.721 & 0.570 & -0.562 & $1 / 18$ & -0.031 & 0.394 \\
\hline \multirow{9}{*}{9} & \multirow{3}{*}{9.1} & 9.1 .2 & 1474.3 & 1643.0 & 1900 & $\uparrow d$ & 0.897 & 0.604 & 0.542 & -0.613 & $1 / 15$ & -0.041 & \\
\hline & & 9.1 .3 & 5166.8 & 4262.3 & 6000 & $\downarrow w$ & 1.212 & 2.086 & 2.528 & 0.927 & $1 / 15$ & 0.062 & \\
\hline & & 9.1 .4 & 51.7 & 62.9 & 45.0 & 个 w & 1.217 & 2.672 & 3.251 & 1.179 & $1 / 15$ & 0.079 & \\
\hline & 9.2 & 9.2 .1 & 60.3 & 69.9 & 75.0 & $\uparrow d$ & 0.863 & 0.347 & 0.299 & -1.206 & $1 / 5$ & -0.241 & \\
\hline & \multirow{2}{*}{9.4} & 9.4 .2 & 4.7 & 3.8 & 11.8 & $\downarrow w$ & 1.237 & 1.127 & 1.394 & 0.332 & $1 / 10$ & 0.033 & \\
\hline & & 9.4 .3 & 21.2 & 21.6 & 29.0 & $\uparrow d$ & 0.981 & 0.949 & 0.931 & -0.072 & $1 / 10$ & -0.007 & \\
\hline & \multirow{2}{*}{9.5} & 9.5 .1 & 0.55 & 0.43 & 3.00 & $\downarrow w$ & 1.279 & 1.049 & 1.342 & 0.294 & $1 / 10$ & 0.029 & \\
\hline & & 9.5 .2 & 1.4 & 1.3 & 15.0 & $\downarrow w$ & 1.077 & 1.007 & 1.085 & 0.082 & $1 / 10$ & 0.008 & \\
\hline & 9.6 & 9.6 .1 & 14 & 62 & 100 & $\uparrow d$ & 0.226 & 0.442 & 0.100 & -2.304 & $1 / 5$ & -0.461 & 0.417 \\
\hline \multirow{4}{*}{10} & \multirow{3}{*}{10.3} & 10.3 .1 & 39.9 & 39.2 & 15.0 & $\downarrow d$ & 0.982 & 0.972 & 0.954 & -0.047 & $1 / 6$ & -0.008 & \\
\hline & & 10.3 .2 & 26.3 & 29.6 & 10.0 & $\uparrow w$ & 1.125 & 1.202 & 1.353 & 0.302 & $1 / 6$ & 0.050 & \\
\hline & & 10.3 .3 & 22.7 & 24.4 & 10.0 & $\uparrow w$ & 1.075 & 1.134 & 1.219 & 0.198 & $1 / 6$ & 0.033 & \\
\hline & 10.5 & 10.5 .1 & 31.0 & 33.1 & 40.0 & $\uparrow d$ & 0.937 & 0.767 & 0.718 & -0.331 & $1 / 2$ & -0.165 & 0.086 \\
\hline \multirow{4}{*}{11} & \multirow{3}{*}{11.3} & 11.3 .1 & 7 & 7 & 13 & $\uparrow d$ & 1 & 1.000 & 1.000 & 0.000 & $1 / 6$ & 0.000 & \\
\hline & & 11.3 .2 & 891 & 992 & 1305 & $\uparrow d$ & 0.898 & 0.756 & 0.679 & -0.387 & $1 / 6$ & -0.065 & \\
\hline & & 11.3 .3 & 3.72 & 4.24 & 8.85 & $\uparrow d$ & 0.877 & 0.899 & 0.788 & -0.238 & $1 / 6$ & -0.040 & \\
\hline & 11.5 & 11.5 .1 & 34 & 36 & 15 & $\uparrow w$ & 1.059 & 1.105 & 1.170 & 0.157 & $1 / 2$ & 0.079 & 0.025 \\
\hline \multirow{9}{*}{12} & \multirow{5}{*}{12.1} & 12.1.1.1 & 100.0 & 95.3 & 60.0 & $\downarrow d$ & 0.953 & 0.883 & 0.841 & -0.173 & $1 / 15$ & -0.012 & \\
\hline & & 12.1 .1 .2 & 100.0 & 97.2 & 60.0 & $\downarrow d$ & 0.972 & 0.930 & 0.904 & -0.101 & $1 / 15$ & -0.007 & \\
\hline & & 12.1.1.3 & 100.0 & 83.8 & 60.0 & $\downarrow d$ & 0.838 & 0.595 & 0.499 & -0.696 & $1 / 15$ & -0.046 & \\
\hline & & 12.1 .1 .4 & 100.0 & 95.2 & 60.0 & $\downarrow d$ & 0.952 & 0.880 & 0.838 & -0.177 & $1 / 15$ & -0.012 & \\
\hline & & 12.1 .1 .5 & 100.0 & 104.0 & 60.0 & 个 w & 1.04 & 1.100 & 1.144 & 0.135 & $1 / 15$ & 0.009 & \\
\hline & \multirow{2}{*}{12.2} & 12.2 .1 & 2.3 & 1.8 & 0.5 & $\downarrow d$ & 0.783 & 0.722 & 0.566 & -0.570 & $1 / 6$ & -0.095 & \\
\hline & & 12.2 .2 & 12.3 & 10.6 & 5.0 & $\downarrow d$ & 0.862 & 0.767 & 0.661 & -0.414 & $1 / 6$ & -0.069 & \\
\hline & 124 & 12.4 .1 & 977.4 & 1015.7 & 800.0 & $\uparrow w$ & 1.039 & 1.216 & 1.263 & 0.234 & $1 / 6$ & 0.039 & \\
\hline & 12.4 & 12.4 .2 & 30.0 & 29.7 & 55.0 & $\downarrow d$ & 0.99 & 1.012 & 1.002 & 0.002 & $1 / 6$ & 0.000 & 0.175 \\
\hline & 14.1 & 14.1 .1 & 29 & 15 & 5 & $\downarrow d$ & 0.517 & 0.417 & 0.215 & -1.535 & $1 / 3$ & -0.512 & \\
\hline 14 & & 14.2 .1 & 5.81 & 5.93 & 10.00 & $\uparrow d$ & 0.980 & 0.971 & 0.952 & -0.049 & $1 / 6$ & -0.008 & \\
\hline 14 & & 14.2 .2 & 612.8 & 625.9 & 752.5 & $\uparrow w$ & 1.021 & 0.906 & 0.925 & -0.078 & $1 / 6$ & -0.013 & \\
\hline & 14.3 & 14.3 .1 & 34.2 & 30.2 & 40.0 & $\downarrow w$ & 1.132 & 1.690 & 1.913 & 0.649 & $1 / 3$ & 0.216 & 0.271 \\
\hline
\end{tabular}


Table A1 (cont.). Calculation of the integral change readiness indicator in accordance with the SDGs in Ukraine

\begin{tabular}{|c|c|c|c|c|c|c|c|c|c|c|c|c|c|}
\hline $\begin{array}{l}\text { 号 } \\
\text { nิ }\end{array}$ & & 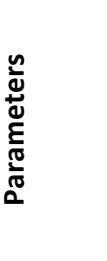 & 号 & 윰 & 芦 & 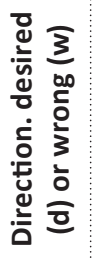 & 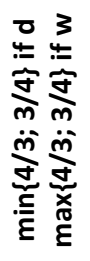 & 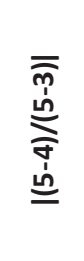 & $\underset{\substack{\infty\\
}}{ }$ & $\begin{array}{l}\bar{a} \\
\underline{\underline{a}}\end{array}$ & $\begin{array}{l}\frac{n}{\frac{5}{000}} \\
\frac{0}{3}\end{array}$ & 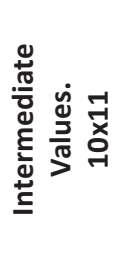 & 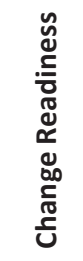 \\
\hline \multirow{10}{*}{15} & \multirow{3}{*}{15.1} & 15.1 .1 & 3803.13 & 4082.20 & 9053.20 & $\uparrow d$ & 0.932 & 0.947 & 0.882 & -0.125 & $1 / 9$ & -0.014 & \\
\hline & & 15.1 .2 & 6.3 & 6.76 & 15.00 & $\uparrow d$ & 0.932 & 0.947 & 0.883 & -0.125 & $1 / 9$ & -0.014 & \\
\hline & & 15.1 .3 & 38.16 & 38.16 & 41.00 & $\uparrow d$ & 1 & 1.000 & 1.000 & 0.000 & $1 / 9$ & 0.000 & \\
\hline & \multirow{5}{*}{15.3} & 15.3 .2 & 32531.1 & 32544.2 & 28370.7 & $\uparrow w$ & 1 & 1.003 & 1.003 & 0.003 & $1 / 15$ & 0.000 & \\
\hline & & 15.3 .3 & 53.9 & 53.9 & 47.0 & $\uparrow d$ & 1 & 1.000 & 1.000 & 0.000 & $1 / 15$ & 0.000 & \\
\hline & & 15.3 .4 & 410.55 & 309.1 & 3000.0 & $\downarrow w$ & 1.328 & 1.039 & 1.380 & 0.322 & $1 / 15$ & 0.021 & \\
\hline & & 15.3 .5 & 7848.3 & 7820.8 & 9536.0 & $\downarrow w$ & 1.004 & 1.016 & 1.020 & 0.020 & $1 / 15$ & 0.001 & \\
\hline & & 15.3 .6 & 13.0 & 13.0 & 15.8 & $\uparrow d$ & 1 & 1.000 & 1.000 & 0.000 & $1 / 15$ & 0.000 & \\
\hline & \multirow{2}{*}{15.4} & 15.4 .1 & 656.72 & 683.80 & 1533.00 & $\uparrow d$ & 0.960 & 0.969 & 0.930 & -0.072 & $1 / 6$ & -0.012 & \\
\hline & & 15.4 .2 & 1.09 & 1.13 & 2.54 & $\uparrow d$ & 0.965 & 0.972 & 0.938 & -0.064 & $1 / 6$ & -0.011 & 0.027 \\
\hline \multirow{4}{*}{16} & \multirow{2}{*}{16.3} & 16.3.1.1 & 5 & 16 & 55 & $\uparrow d$ & 0.313 & 0.780 & 0.244 & -1.410 & $1 / 6$ & -0.235 & \\
\hline & & 16.3 .1 .2 & 16 & 34 & 55 & $\uparrow d$ & 0.471 & 0.538 & 0.254 & -1.372 & $1 / 6$ & -0.229 & \\
\hline & 16.4 & 16.4 .1 & 24.32 & 25.00 & 13.00 & $\uparrow w$ & 1.028 & 1.060 & 1.090 & 0.086 & $1 / 3$ & 0.029 & \\
\hline & 16.5 & 16.5.1 & 3063 & 2985 & 2500 & $\downarrow d$ & 0.975 & 0.861 & 0.840 & -0.174 & $1 / 3$ & -0.058 & 0.389 \\
\hline \multirow{2}{*}{17} & \multirow{2}{*}{17.1} & 17.1 .1 & 7.6 & 7.8 & 6.0 & $\uparrow w$ & 1.026 & 1.125 & 1.154 & 0.143 & $1 / 2$ & 0.072 & \\
\hline & & 17.1 .2 & 3012 & 2422 & 17500 & $\downarrow w$ & 1.244 & 1.041 & 1.295 & 0.258 & $1 / 2$ & 0.129 & -0.222 \\
\hline
\end{tabular}

